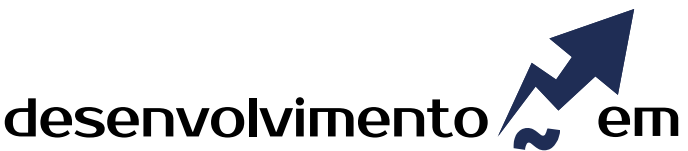 QUESTÃO
}

\section{A Abordagem Effectuation em Empreendedorismo Social}

\author{
Ronalty Oliveira Rocha, ${ }^{1}$ Joenison Batista da Silva, ${ }^{2}$ \\ Rivanda Meira Teixeira, ${ }^{3}$ Ludmilla Meyer Montenegro ${ }^{4}$
}

http://dx.doi.org/10.21527/2237-6453.2019.46.88-111

Recebido em: $18 / 3 / 2017$

Aceito em: 4/9/2018

\begin{abstract}
RESUMO
Entendendo que o ambiente dos negócios sociais é repleto de incertezas e contingências, e reconhecendo a importância das organizações sem fins lucrativos, que têm demonstrado serem atuantes para o bem-estar da coletividade, este estudo analisa a criação de empreendimentos sociais sob a abordagem Effectuation. Este trabalho objetivou identificar como os princípios effectuation de definição de meios, perdas acessíveis, alianças estratégicas e alavancagem de contingências, propostos por Sarasvathy (2001), formatam a criação de empreendimentos sociais. Para tanto foi realizado um estudo qualitativo de casos múltiplos, de natureza exploratória, em empreendimentos sociais de Sergipe. Os dados foram coletados por meio de entrevista semiestruturada com dois empreendedores sociais de Sergipe, e o conteúdo das entrevistas foi analisado com base na análise de conteúdo. Os resultados indicam que empreendedores sociais aplicam elementos de effectuation em suas empresas, principalmente a definição de meios, quando se envolvem em negócios a partir de suas características pessoais, profissionais e redes de contatos. A celebração de parcerias estratégicas, sem caráter formal, foi evidenciada como primordial à criação e continuidade de negócios sociais. Por fim, os princípios de perdas acessíveis e alavancagem de contingências foram os menos evidenciados nos casos.
\end{abstract}

Palavras-chave: Empreendedorismo social. Effectuation. Criação de negócios sociais.

\section{EFFECTUATION APPROACH ON SOCIAL ENTREPRENEURSHIP}

\section{ABSTRACT}

Knowing that the social business environment is full of uncertainties and contingencies and recognizing the importance of non-profit organizations, which have shown their performance concerning the collectivity well-being, this study analyzes the process of creation of social enterprises based on the Effectuation approach. This paper intended to identify how the effectuation concepts of definition of means, affordable losses, strategic alliances and contingencies leverage, proposed by Sarasvathy (2001), format the creation of social enterprises. For this purpose, a qualitative and exploratory multiple case study was conducted in social enterprises in the state of Sergipe, Brazil. The data were collected through semi structured interviews with two social entrepreneurs of Sergipe and the content of the interviews was analyzed through content analysis. The results suggest that the social entrepreneurs apply elements of effectuation in their businesses, especially the definition of means, when they get involved in businesses based on their personal and professional characteristics and network. The celebration of strategic partners, without formal nature, was revealed as principal to the creation and continuity of the social businesses. At last, the concepts of affordable losses and the contingencies leverage were the less highlighted in the cases.

Keywords: Social entrepreneurship. Effectuation. Creation of social businesses.

\footnotetext{
${ }^{1}$ Mestre em Administração pela Universidade Federal de Sergipe (UFS).ronaltyrocha@gmail.com

${ }^{2}$ Mestre em Administração pela Universidade Federal de Sergipe (UFS). joenisonbatista@hotmail.com

${ }^{3}$ Doutora em Administração pela Cranfield University, Inglaterra. Professora do Programa de Pós-Graduação em Administração da Universidade Federal do Paraná (UFPR). rivandateixeira@gmail.com

${ }^{4}$ Doutora em Administração pela Universidade Federal do Paraná (UFPR). Professora do Programa de Pós-Graduação em Administração da Universidade Federal de Sergipe (UFS). ludmilla2907@gmail.com
} 
O crescente processo de exclusão social em todo o mundo, que vem sendo agravado pelas intensas crises econômicas, tem tornado evidente a incapacidade dos governos em lidar com grandes demandas sociais, como saúde, educação, lazer e moradia. Neste cenário, o surgimento de projetos sociais tem se tornado frequente, tais como organizações sem fins lucrativos com o objetivo de criar valor social e melhorar a qualidade de vida da coletividade. Aliás, essas iniciativas em empreendedorismo social têm sido vistas com grande potencial de aliviar muitos dos males enfrentados pela sociedade moderna (VANSANDT; SUD; MARMÉ, 2009). Além disso, o empreendedorismo social tornou-se um conceito muito discutido no mundo dos negócios, e não só tem atraído atenção da literatura acadêmica, como também recursos financeiros e pessoas de talento (NOGUEIRA; NOGUEIRA, 2012).

Nesse sentido, em razão do contexto social, econômico e político em que organizações sem fins lucrativos operam, caracterizado por elevados níveis de incerteza e recursos limitados, essas organizações, muitas vezes, não se encaixam numa perspectiva linear para tomadas de decisão e definição de estratégias (OHLSSON-CORBOZ, 2013). Neste contexto, desponta a abordagem effectuation, proposta por Sarasvathy (2001), que busca explicar a criação de empreendimentos na ausência ou limitação de recursos.

Nessa abordagem, os empreendedores não assumem metas predeterminadas e pormenorizadas. As metas emergem diante de incertezas e contingências do ambiente empresarial. Mais que isso, a lógica effectuation defende que os empreendedores sejam capazes de criar oportunidades na ausência de recursos, e mudar objetivos e cursos de ação com base em contingências e eventos que venham a surgir inesperadamente (SARASVATHY, 2001; GALKINA; CHETTY, 2015). Além disso, Ohlsson-Corboz (2013) reforça que a incerteza está presente em todos os níveis empresariais, principalmente em empreendimentos sociais que vivem de doações, e a teoria effectuation é um valioso instrumento teórico para exibir e compreender os processos de criação e tomadas de decisão nesses empreendimentos.

Ressalta-se que, no Brasil, vários estudos têm abordado a lógica effectuation, principalmente para retratar a criação de empreendimentos comerciais, a exemplo de Pelogio et al. (2011), que analisaram a criação de empresas por mulheres empreendedoras buscando verificar se elas utilizaram processos decisórios alinhados à lógica effectuation. Destaca-se também o trabalho de Silva, Teixeira e Montenegro (2014), que analisaram se os empreendedores de spin-offs estudantis utilizaram a abordagem effectuation na criação de seus negócios. Além destes, destacam-se, também, os trabalhos de Vieira e Brito (2014), que buscaram identificar princípios de effectuation na criação de uma empresa de aluguel de livros; o estudo de Gonzalez, Anez e Machado (2011), o qual objetivou compreender a lógica adotada por um empreendedor brasileiro durante o processo de criação de um novo negócio, com o fim de compreender a predominância, nesse processo, de um raciocínio causal tradicional ou de um raciocínio effectual; e o estudo de Sarmento, Carvalho e Dib (2016), que analisou o processo de internacionalização de empresa por meio da teoria de effectuation.

No tocante ao empreendedorismo social, Wusu e Janssen (2013) reforçam que pouca pesquisa tem sido realizada para identificar os fatores e processos de tomadas de decisão, que influenciam o lançamento e sustentabilidade desses empreendimentos. 
Por este motivo a associação entre o empreendedorismo social e a lógica effectuation parece ser útil para explicar o processo de decisão utilizado por atores envolvidos na criação de empreendimentos sociais.

Assim, o objetivo geral deste estudo foi analisar o processo de criação de empreendimentos sociais a partir da abordagem effectuation. Especificamente buscou-se identificar a motivação inicial de empreendedores para criar negócios sociais; analisar como perdas e riscos toleráveis formatam a criação de um empreendimento social e explorar o papel das parcerias ao longo do processo. A estratégia de pesquisa adotada foi o estudo de casos múltiplos em dois empreendimentos sociais de Sergipe.

Do ponto de vista teórico este trabalho incrementa os resultados de estudos sobre a lógica effectuation, assim como agrega evidências da aplicabilidade dessa abordagem em empreendimentos sociais. Do ponto de vista prático, auxilia empreendedores sociais ao destacar como os princípios de effectuation podem ser utilizados no processo de tomadas de decisão para criação de negócios sociais, bem como para melhorar o desempenho deste tipo de empreendimento.

\section{EMPREENDEDORISMO SOCIAL}

Devido ao crescente processo de exclusão social em todo o mundo, estão surgindo organizações com finalidade social que operam em diversas áreas, cujo objetivo é buscar soluções para os diversos problemas sociais, que vão desde a sustentabilidade ambiental à erradicação da miséria e à redução da desigualdade socioeconômica (BOSE, 2012).

A expressão empreendedorismo social surgiu entre as décadas de 80 e 90 do século 20 para tratar dos problemas associados a novas ou persistentes necessidades sociais, tais como habitação, saúde, trabalho e alfabetização, que vinham chamando a atenção de vários setores da sociedade (MARTIN; OSBERG, 2007; QUINTÃO, 2011). Conforme evidenciado por Barki (2015), o empreendedorismo social surgiu em decorrência de uma avaliação crítica feita aos sistemas econômicos neoliberais, bem como por meio de diversos dilemas sociais, o que acabou por resultar em um novo grupo de indivíduos empreendedores que visavam à solução de problemas da sociedade e à criação de valor social.

Esse valor social pode ser entendido como o resultado, pautado nos princípios da inovação social, do trabalho com pessoas, redes e parcerias cuja centralidade é o empreendimento social (PARENTE, 2014). Assim, empreendedorismo social pode, então, ser visualizado como um processo que envolve a utilização e combinação inovadora de recursos para buscar catalisar e atender necessidades sociais (NOGUEIRA; NOGUEIRA, 2012).

Os empreendedores sociais, assim como os tradicionais, são indivíduos proativos, inovadores e com aptidão para gestão de risco (OHLSSON-CORBOZ, 2013). Conforme defendido por Mair e Martí (2006), entretanto, um dos principais aspectos que diferencia o empreendedor tradicional do empreendedor social é especificamente o objetivo central de suas atividades. Ao passo que o empreendedor social pretende a criação de riqueza social e de benfeitorias para a sociedade, os empreendedores tradicionais demandam sua motivação para a obtenção do lucro. Cabe ressaltar, porém, que mes- 
mo que o motivo central deste último seja o aspecto financeiro, isso não o impede de possuir outras motivações, inclusive de desempenhar atividades voltadas para o cerne social.

De acordo com a Miranda et al. (2016), os empreendedores voltados para o cerne social são vistos como indivíduos que, de alguma forma, desenvolvem soluções inovadoras, as quais poderão sanar os problemas mais evidentes em determinada sociedade. Deve-se destacar que esses indivíduos são geralmente ambiciosos e muito persistentes, buscando constantemente desenvolver novas ideias que possam resultar na instituição de soluções até então não colocadas em prática.

Campos et al. (2012) apresentam como qualidade básica dos empreendedores sociais o foco de preocupação sobre questões sociais e coletivas. Corroborando essa ideia, Hoogendoorn, Pennings e Thurik (2010) definem o empreendedor social como um ator que está apto a responder, de forma inovadora, a problemas e necessidades sociais. Ou seja, os empreendedores sociais, no âmbito de suas atividades, buscam oferecer um laboratório de construção da aprendizagem, desenvolvendo e colocando em prática inovações e soluções voltadas para a solução de problemas sociais (DEES, 2009).

Quanto à tipologia desses indivíduos, Campos et al. (2012) identificaram quatro tipos de empreendedores sociais. O primeiro, oriundo do trabalho de Oliver e Mckague (2009), refere-se ao bricolor social, ou seja, empreendedores que conseguem, por meio de suas habilidades pessoais, se sobreporem à escassez de recursos necessários para iniciar um empreendimento social (FISHER, 2012). Corroborando essa perspectiva, Dees (2009) salienta que os empreendedores sociais são bastante habilidosos no tocante ao desempenho de suas atividades, tendo em vista que eles conseguem desempenhar atividades de grande impacto social com uma baixa disponibilidade de recursos.

O segundo tipo está relacionado às empresas privadas que promovem ações de caráter social, mesmo não sendo a finalidade principal do negócio. O terceiro tipo é representado pelo terceiro setor, entidades com estrutura organizacional definida e delimitação quanto ao porte e amplitude de atuação (FISCHER, 2011). A quarta tipologia refere-se ao agrupamento de pessoas que se unem em torno de uma causa social a qual pode evoluir para gerar relações jurídicas formais, como associações ou cooperativas.

Muito se discute no campo do empreendedorismo social sobre aspectos relacionados à identificação de oportunidades (CORNER; HO, 2010). Nesse contexto, os autores Gouvêa e Cautela (2014) explanam que os empreendedores sociais pensam constantemente no bem da sociedade, buscando de alguma forma identificar novas oportunidades de melhorias sociais. Esses empreendedores não medem esforços para conseguir colocar seus projetos em prática, mesmo que isso leve a uma maior propensão aos riscos, fator este que se torna pequeno perto do desejo de desenvolver projetos de mudança social.

Korsgaard (2011) enfatiza que as oportunidades sociais surgem de um processo de mobilização e transformação de recursos. Ohlsson-Corboz (2013) salienta que os empreendedores sociais identificam as oportunidades nos problemas da sociedade, visando a amenizar dificuldades sociais que as instituições governamentais não conseguiram resolver de forma eficaz e sustentável. Corroborando essa ideia, Martin e Osberg (2015) observam que os empreendedores sociais são capazes de solucionar problemas 
que poderiam ser resolvidos por meio de ações desenvolvidas tanto pelo poder público como pela iniciativa privada. Os autores ainda destacam que o empreendedorismo social surgiu como uma maneira de enxergar os problemas sociais até então não sanados, e com isso promover meios de mudanças que possam de alguma forma transformar a sociedade.

Para Seelos e Mair (2005) o empreendedorismo social cria novos modelos para o fornecimento de produtos e serviços que atendam diretamente às necessidades humanas, além de tentar solucionar problemas sociais por meio da mobilização de recursos (YUNUS, 2008). Nesse mesmo teor, Miranda et al. (2016) explanam que para alcançar o sucesso com os empreendimentos sociais é necessário saber lidar com as possíveis e quase sempre presentes restrições financeiras, visando sempre ao bem-estar social em detrimento de interesses próprios.

Ao contrário do que muitos imaginam, no entanto, o empreendedorismo social não gera apenas valor social, mas também proporciona a geração de empregos e riqueza (MARTÍ; SORIANO; MARQUÉS, 2016). Dacin, Dacin e Tracey (2011) explicam que empresas sociais equilibram dois conjuntos de prioridades; portanto possuem foco tanto na criação de valor social como também de valor econômico, tendo em vista que este segundo é crucial para a manutenção dos empreendimentos. Hill, Kothari e Shea (2010) destacam que com o propósito de cumprir sua missão social, os empreendimentos sociais, mesmo sem fins lucrativos, devem ter um foco de gestão empresarial centralizado na sustentabilidade do negócio.

O Quadro 1 resume as ideias teóricas centrais abordadas nessa seção.

Quadro 1 - Principais Elementos Teóricos do Empreendedorismo Social

\begin{tabular}{|l|l|}
\hline \multicolumn{1}{|c|}{ Assuntos } & \multicolumn{1}{c|}{ Autores consultados } \\
\hline $\begin{array}{l}\text { Empreendedorismo } \\
\text { social (conceitos) }\end{array}$ & $\begin{array}{l}\text { Seelos; Mair (2005); Martin; Osberg (2007); Yunus, (2008); Korsgaard } \\
\text { (2011); Quintão (2011); Nogueira; Nogueira (2012); Gouvêa; Cautela } \\
\text { (2014); Barki (2015); Martin; Osberg (2015); Martí; Soriano; Marqués } \\
\text { (2016); Miranda et al. (2016). }\end{array}$ \\
\hline $\begin{array}{l}\text { Empreendimento } \\
\text { social }\end{array}$ & $\begin{array}{l}\text { Hill, Kothari e Shea (2010); Dacin, Dacin, Tracey (2011); Bose (2012); } \\
\text { Parente (2014). }\end{array}$ \\
\hline Empreendedor social & $\begin{array}{l}\text { Mair; Martí (2006); Dees (2009); Oliver; Mckague (2009); } \\
\text { Hoogendoorn; Pennings, Thurik (2010); Fischer (2011); Korsgaard } \\
\text { (2011); Campos et al. (2012); Ohlsson-Corboz (2013); Gouvêa; Cautela } \\
\text { (2014); Barki (2015), Martin; Osberg (2015); Miranda et al. (2016). }\end{array}$ \\
\hline
\end{tabular}

Fonte: Elaborado pelos autores a partir da revisão da literatura (2017).

Diante do exposto, e com base no cerne dos empreendimentos sociais e dos processos de tomadas de decisão nesses empreendimentos, a próxima seção abordará os aspectos relativos à lógica effectuation, a qual, conforme enaltecido por Sarasvathy (2008), pode estar presente nos diversos tipos de empreendimentos, inclusive naqueles de âmbito social. 


\section{A LÓGICA EFFECTUATION}

No campo de estudos do empreendedorismo, várias pesquisas têm se dedicado a entender quais as lógicas de raciocínio prevalecentes para as tomadas de decisão. Nesse contexto, Sarasvathy (2001) apresenta a ideia do nexo causation e effectuation como abordagens características do comportamento empreendedor, e frequentemente percebidas em todos os níveis de atividade empresarial.

Conforme entendimento de Sarasvathy (2001), a maior parte dos empresários tende a tomar decisões embasadas numa lógica causation, de cunho racional, que se caracteriza, prioritariamente, pela predefinição de metas. Essa lógica se explica por "processos em que efeitos desejados são definidos e se concentra em selecionar, entre meios já existentes, mecanismos para criar esse efeito" (SARASVATHY, 2001, p. 245).

Kupper e Burkhart (2009), assim como Chandler et al. (2011), explicam que ao utilizar a lógica causal para tomada de decisão, os empreendedores partem de um conhecimento preexistente, com um objetivo predeterminado, pelo qual desenham esquemas competitivos com foco em retornos esperados, a partir de previsões de um futuro incerto, do qual incertezas e contingências são evitadas e minimizadas por meio de pesquisas e análises de mercado. Nessa abordagem o empreendedor seleciona, apenas, possibilidades racionalmente previsíveis (MAINE; SOH; SANTOS, 2015). Nesse contexto, Sharma e Salvato (2011) destacam a abordagem causation como a mais apropriada à busca e exploração de oportunidades em ambientes estáveis.

Em oposição ao entendimento predominante de que empreendedores se baseiam na plena racionalidade para criação de novos negócios, Sarasvathy (2001) expõe que, no ambiente empresarial, os agentes não reagem de um mesmo modo e nem têm acesso às mesmas informações para tomadas de decisão. Nesse enredo, entendimentos sobre risco, informação imperfeita, contingências e incertezas ganham destaque na análise econômica. Partindo de tal percepção a autora propõe a abordagem effectuation como uma nova perspectiva sobre o empreendedorismo e seus processos de reconhecimento e exploração de oportunidades (Figura 1).

Divergente da lógica causation, a abordagem effectuation não assume metas predeterminadas e pormenorizadas, visto que considera que essas metas emergem diante de incertezas e contingências do ambiente empresarial (SARASVATHY, 2008). O processo effectual caracteriza-se, então, por "tomar um conjunto de meios como dado, e se concentrar em selecionar entre possíveis efeitos que podem ser criados com esse conjunto de meios" (SARASVATHY, 2001, p. 245).

Figura 1 - Processo Causal e Effectuation

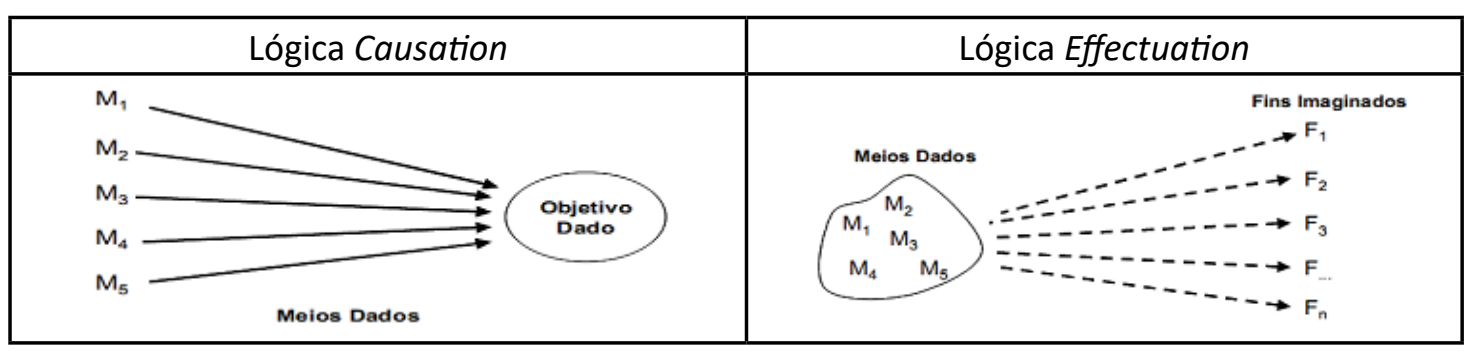

Fonte: SARASVATHY (2001). 
Sarasvathy e Dew (2005) detalham que o empreendedor dispõe de três diferentes meios que o influenciam na decisão de iniciar um negócio: 1) quem eu sou - atributos pessoais, gostos e habilidades - o empreendedor segue estratégias com as quais mais se identifica, mesmo sem maiores certezas quanto aos possíveis resultados; 2) o que eu sei - educação, experiência e expertise - quais oportunidades podem ser exploradas a partir do conhecimento do empreendedor e 3) quem eu conheço - redes sociais e profissionais - interação com partes interessadas (stakeholders) para modelar e remodelar projetos e objetivos do negócio.

Para melhor explanação da lógica effectuation, Sarasvathy (2001), com posterior apreciação de Read, Song e Smit (2009), propõe quatro princípios que caracterizam essa abordagem: (1) Perdas acessíveis - o empreendedor define, antecipadamente, um nível aceitável para perdas, e busca opções que criem mais opções no futuro àquelas que maximizam, apenas no presente, o retorno esperado. O que importa na perda acessível não é o risco inerente à indústria ou ao empreendimento individual, mas o quanto o empreendedor sabe administrar esse risco; (2) Alianças estratégicas - enfatiza parcerias por meio de pré-compromissos com partes interessadas, como forma de reduzir incertezas e erguer barreiras à entrada de concorrentes. Um empresário ou uma empresa pode construir muitos relacionamentos, mas apenas aqueles em que ambas as partes partilham os riscos e benefícios do empreendimento constituem parcerias eficazes; (3) Alavancagem de contingências - aproveitamento de situações inesperadas para remodelar objetivos e explorar novas oportunidades. Este princípio faz da incerteza um ativo, eliminando a necessidade de evitá-la. É importante que o empreendedor tenha coragem e disposição para mudar quando confrontado com novas informações, meios ou surpresas; (4) Controlar um futuro imprevisível - o controle é obtido por intermédio da definição dos meios disponíveis, as escolhas feitas e a qualidade das relações com partes interessadas.

Pautados nesses princípios, os empreendedores são capazes de criar oportunidades, estruturar negócios na ausência de recursos e tomar decisões diante de mercados não existentes (OHLSSON-CORBOZ, 2013), assim como de mudar seus objetivos iniciais ou cursos de ação com base em novas informações e/ou contingências que venham a surgir inesperadamente (DANIEL; DI DOMENICO; SHARMA, 2015). Logo, os empreendedores são vistos como moldadores e criadores de seu ambiente imediato, e não apenas como agentes preditivos para eventos do ambiente empresarial (WERHAHN et al., 2015).

Além disso, Sarasvathy (2008) destaca que os princípios de effectuation diminuem os custos do fracasso, uma vez que permitem ao empreendedor falhar já nos estágios iniciais do negócio e em níveis mais baixos de investimentos. Nessa acepção, a lógica effectuation desponta como uma abordagem para tomada de decisão que proporciona uma maior resistência a choques externos, mudanças ambientais e retrocessos (MAINE; SOH; SANTOS, 2015).

A lógica effectuation está associada com um espectro de movimento, que não apenas detecta e reconhece oportunidades com retorno mais elevado, mas que principalmente estimula a percepção, imaginação e interação humana, e humana-ambiente, para criação e exploração de oportunidades (SARASVATHY, 2008; MAINE; SOH; SANTOS, 2015; CORNER; HO, 2010). 
Para melhor compreensão das lógicas effectual e causal apresenta-se o Quadro 2 com os principais pressupostos e diferenças entre essas abordagens.

Quadro 2 - Diferenças entre a lógica causal e effectual

\begin{tabular}{|l|l|l|}
\hline \multicolumn{1}{|c|}{ Pressuposto } & \multicolumn{1}{|c|}{ Quadro causal } & \multicolumn{1}{c|}{ Quadro effectual } \\
\hline $\begin{array}{l}\text { Visão do } \\
\text { futuro }\end{array}$ & $\begin{array}{l}\text { Preditiva. Molda o futuro como } \\
\text { uma continuação do passado. } \\
\text { Previsão precisa, necessária e útil. }\end{array}$ & $\begin{array}{l}\text { Criativa. Molda o futuro a partir de } \\
\text { ações intencionais. A previsão não é } \\
\text { nem fácil, nem útil. }\end{array}$ \\
\hline $\begin{array}{l}\text { Base para as } \\
\text { tomadas de } \\
\text { decisão }\end{array}$ & $\begin{array}{l}\text { Objetivo-orientado. Objetivos } \\
\text { determinam as ações, incluindo } \\
\text { quais indivíduos irão executá-las. }\end{array}$ & $\begin{array}{l}\text { Significado-orientado. Objetivos } \\
\text { emergem a partir de cursos de ação } \\
\text { com base em meios dados. }\end{array}$ \\
\hline $\begin{array}{l}\text { Predisposição } \\
\text { para riscos e } \\
\text { recursos }\end{array}$ & $\begin{array}{l}\text { Retorno esperado. Novos } \\
\text { empreendimentos são guiados a } \\
\text { explorar oportunidades sob certo } \\
\text { nível de risco. Foco no potencial de } \\
\text { retorno sobre o investimento. }\end{array}$ & $\begin{array}{l}\text { Perda acessível. Busca de novas } \\
\text { oportunidades sem investir mais } \\
\text { recursos, as partes interessadas podem } \\
\text { definida. Foco na limitação do potencial } \\
\text { de desvantagem. }\end{array}$ \\
\hline $\begin{array}{l}\text { Atitude em } \\
\text { relação a } \\
\text { estranhos }\end{array}$ & $\begin{array}{l}\text { Análise competitiva. Relações } \\
\text { são operacionalizadas por } \\
\text { concorrência e análises } \\
\text { competitivas. }\end{array}$ & $\begin{array}{l}\text { Parcerias. Busca constante por parcerias } \\
\text { para criar novos negócios e explorar } \\
\text { novos mercados. }\end{array}$ \\
\hline $\begin{array}{l}\text { Atitudes em } \\
\text { relação a } \\
\text { contingências }\end{array}$ & $\begin{array}{l}\text { Evitamento. Previsões precisas, } \\
\text { planejamento firme e cuidadoso } \\
\text { com foco em definir metas. } \\
\text { Contingências são vistas como } \\
\text { obstáculos e devem ser evitadas. }\end{array}$ & $\begin{array}{l}\text { Aproveitamento. Contingências são } \\
\text { vistas como oportunidades para a } \\
\text { criação, novidade e inovação. }\end{array}$ \\
\hline
\end{tabular}

Fonte: DEW et al. (2009).

Ressalta-se que as abordagens causation e effectuation não são excludentes e podem se manifestar de forma simultânea, ou intercaladamente no comportamento empreendedor (SARASVATHY, 2008) e não cabe definir uma abordagem como melhor ou pior. A adoção de cada processo e os resultados alcançados por meio dele resultará de cada situação e de suas particularidades (HARMS; SCHIELE, 2012).

O Quadro 3 resume os principais aspectos relacionados à lógica effectuation abordados neste trabalho.

Quadro 3 - Principais Aspectos da Lógica Effectuation

\begin{tabular}{|l|l|l|}
\hline \multicolumn{2}{|c|}{ Assuntos } & \multicolumn{1}{c|}{ Autores consultados } \\
\hline \multirow{2}{|l|}{ Lógica causation } & $\begin{array}{l}\text { Sarasvathy (2001); Kupper; Burkhart (2009) } \\
\text { Chandler et al. (2011); Sharma; Salvato (2011); } \\
\text { Maine; Soh; Santos (2015). }\end{array}$ \\
\hline \multirow{3}{*}{$\begin{array}{l}\text { Lógica } \\
\text { Effectuation }\end{array}$} & $\begin{array}{l}\text { Aspectos } \\
\text { conceituais }\end{array}$ & $\begin{array}{l}\text { Sarasvathy (2001); Sarasvathy (2008) } \\
\text { Sarasvathy; Dew (2005); Ohlsson-Corboz, (2013); Werhahn et } \\
\text { al. (2015); Daniel; Di Domenico; Sharma (2015); Maine; Soh; } \\
\text { Santos, 2015; Corner; Ho, (2010); Harms; Schiele, (2012). }\end{array}$ \\
\cline { 2 - 3 } & $\begin{array}{l}\text { Princípios } \\
\text { effectuation }\end{array}$ & $\begin{array}{l}\text { Sarasvathy (2001); Sarasvathy (2008) } \\
\text { Read; Song; Smit (2009); Dew et al. (2009). }\end{array}$ \\
\hline
\end{tabular}

Fonte: Elaborado pelos autores a partir da revisão da literatura (2017). 
Resgata-se aqui, conforme apresentado por Sarasvathy (2001), que a lógica effectuation visa a esclarecer como são criados empreendimentos em situações de escassez e limitação de recursos. Posteriormente, Sarasvathy (2008) reforçou o entendimento de que a lógica effectuation é adequada à compreensão dos processos de criação e tomadas de decisão em todos os tipos de empreendimentos, inclusive naqueles sociais. Nesse contexto a seção a seguir apresenta argumentos que identificam a abordagem effectuation em empreendedorismo social.

\section{EFFECTUATION EM EMPREENDEDORISMO SOCIAL}

Empreendedores, independentemente de finalidade comercial e/ou social, são sempre empreendedores - inovadores, criativos, práticos e oportunistas - e as lógicas causation e/ou effectuation podem estar presentes em seus ambientes e atividades (SARASVATHY, 2008; HARTINGAN; ELKINGTON, 2009).

$\mathrm{O}$ argumento anterior pode ser ratificado pelo entendimento de que empreendimentos sociais são apenas uma forma alternativa de empreendimentos, além de que o empreendedorismo social está incluído no domínio geral do campo de estudos em empreendedorismo, sua especificidade encontra-se na observação de que os empreendedores sociais trabalham para resolver problemas sociais existentes (MARTIN; OSBERG, 2007) com prioridade na criação de riqueza social, ao passo em que empreendedores comerciais trabalham visando à criação de riqueza econômica (MAIR; MARTí, 2006).

Sobre esse assunto, Yusuf e Sloan (2015) defendem que, em razão do contexto social, econômico e político em que organizações sem fins lucrativos operam, caracterizado por elevados níveis de incerteza e recursos limitados, essas organizações, muitas vezes, não se encaixam na perspectiva linear da abordagem causal. Além disso, Vansandt, Sud e Marmé (2010) afirmam que por tratar da tomadas de decisão sob incertezas, a lógica effectuation pode ser visualizada como um dos principais catalisadores para o melhor desempenho de empreendimentos sociais.

Nesse contexto, a abordagem effectual desponta, então, como uma lógica adequada à compreensão dos processos de criação, tomada de decisão, definição de perdas acessíveis e construção de relacionamentos estratégicos em empreendimento sociais.

Outrossim, conforme interpretação de Nogueira e Nogueira (2012), a formação de oportunidade é uma das melhores formas de visualizar a relação entre effectuation e empreendedorismo social. Esse entendimento vai ao encontro da percepção de Corner e Ho (2010), que afirmam existir uma reflexão implícita sobre effectuation nas pesquisas sobre empreendedorismo social, destacadamente quando os autores da área descrevem que as oportunidades sociais surgem e são exploradas em função das idiossincrasias, relacionamentos e redes sociais do empreendedor social.

Além da identificação e exploração de oportunidades, é pertinente também explicar que o empreendedor social é motivado, em razão contexto no qual está inserido, a criar valor social (MAIR; MARTÍ, 2006) e responder a problemas e necessidades sociais de forma inovadora (HOOGENDOORN; PENNINGS; THURIK, 2010). Aliás, Dees (2001) defende que o empreendedor social, a partir de um contexto desafiante assume a missão social de atacar e solucionar problemas, assim como de promover expressivas mudanças no ambiente social em que está inserido. 
Retomando a discussão acerca da formação de oportunidades em empreendedorismo social, Korsgaard (2011) revela que a oportunidade assume diferentes formas no processo empreendedor e que o empreendedor social, dotado de diferentes habilidades e modos de pensar, é aquele que cria, ativamente, circunstâncias externas ao invés de, apenas, responder às oportunidades identificadas, isto é, o empreendedor social pratica aspectos da lógica effectual. Em complemento a esse entendimento Nicholls (2006) e Parente et al. (2011) corroboram a percepção de que os empreendedores sociais, além de identificarem oportunidades sociais, são motivados a transformar a sociedade e serem agentes dessa mudança melhorando sistemas e criando novas soluções.

Outro argumento inerente à associação entre effectuation e empreendedorismo social é apresentado por Ohlsson-Corboz (2013), que declara que elementos do processo effectual podem facilmente ser identificados em empreendimentos sociais, principalmente porque empreendedores sociais criam negócios sem um planejamento mais apurado, e moldam soluções inovadoras ao acessar, por meio de parcerias, recursos que não possuem individualmente. Inclusive, a autora reforça que as parcerias estratégicas são o recurso mais crítico para empresários sociais, pois, sem parcerias (funcionários, voluntários e clientes) verdadeiramente comprometidas, o empreendimento social teria impacto mínimo e poucas chances de sobrevivência.

Ademais, a lógica effectual obriga os empreendedores sociais a desafiarem modelos mentais convencionais levando-os a soluções criativas e inovadoras que resultam em um círculo virtuoso, que conduz a organização social a uma rede em constante expansão, aumento de recursos, maior impacto, reconhecimento, respeito e legitimidade por parte da sociedade mais ampla (VANSANDT; SUD; MARMÉ, 2009).

\section{ASPECTOS METODOLÓGICOS}

Esta pesquisa caracteriza-se como exploratória por buscar estudar a aplicação da teoria effectuation em empreendimentos sociais. A natureza exploratória é reforçada pela não identificação de estudos que trabalhem com essas duas temáticas, conjuntamente, na literatura nacional. No tocante aos objetivos esse estudo é descritivo por tentar compreender e descrever, em detalhes, características específicas da aplicação de princípios effectuation em empreendimentos sociais (NEUMAN, 1997).

A estratégia de pesquisa adotada foi o estudo de casos múltiplos. Segundo Eisenhardt (1989), o estudo de caso é uma estratégia de pesquisa que se concentra na compreensão das dinâmicas presentes dentro de cenários específicos. Na presente pesquisa, o cenário analisado é o da aplicação de princípios effectuation em empreendimentos sociais.

Trata-se de um estudo de casos múltiplos, conforme Yin (2015), por buscar, a partir do estudo de duas unidades de análise, a identificação de padrões centrais para a indicação de algum grau de generalização sobre a aplicação da lógica effectuation em negócios sociais. Para esta pesquisa as unidades de análise foram constituídas por dois empreendimentos sociais. O primeiro deles é uma associação musical que tem como principal atividade a prática coletiva de música. A segunda unidade de análise foi uma creche que tem como principal atividade a alfabetização de crianças até 5 anos. 
Para a seleção dos casos foi realizada uma pesquisa preliminar, em sites e redes sociais, acerca do histórico desses empreendimentos, por meio da qual foi possível identificar elementos de effectuation na constituição dos negócios sociais selecionados. Inicialmente foram considerados três casos, mas um deles foi descartado por não possuir os pressupostos de effectuation, sendo, por essa razão, considerados apenas dois casos para análise.

Para a coleta dos dados foi utilizado um roteiro de entrevista semiestruturado elaborado a partir da revisão da literatura e fundamentado nas seguintes categorias analíticas: características do empreendedor, características do empreendimento social e princípios effectuation. Explica-se que a categoria de características do empreendedor analisou aspectos relacionados aos fundadores dos empreendimentos sociais pesquisados, tais como: idade, estado civil, ocupação e nível de instrução. Referente à categoria de características do empreendimento social foram identificados aspectos relacionados ao tempo de funcionamento, atividades desenvolvidas, público atendido e número de colaboradores. Por fim a categoria de princípios effectuation identificou como os elementos de definição de meios, perdas acessíveis e parcerias estratégicas, propostos por Sarasvathy (2001), formataram os empreendimentos sociais pesquisados.

As entrevistas foram realizadas com fundadores de dois empreendimentos sociais de Sergipe, sendo aplicada uma entrevista com cada empreendedor, no período compreendido entre 10 e 30 de junho de 2016. Além das entrevistas com os empreendedores, outra fonte de evidência adotada foi a consulta ao site institucional e pesquisa em rede social, especificamente no Facebook. Essas informações foram incluídas na descrição das características das empresas.

Os dados foram analisados com base na análise de conteúdo, uma técnica de análise das comunicações, que identifica e analisa aspectos essenciais do que foi dito em entrevistas e observado pelo pesquisador (BARDIN, 2006).

Conforme proposto por Bardin (2006), a análise de conteúdo foi realizada seguindo as seguintes etapas: 1) pré-análise - organização inicial do material das entrevistas, assim como foram, preliminarmente, sistematizadas as ideias evidenciadas no referencial teórico; 2) exploração do material - descrição analítica a respeito das evidências coletadas. Nesta etapa também foram identificadas as palavras e relatos relacionados à lógica effectuation, permitindo assim a codificação, classificação e categorização das evidências identificadas e 3) tratamento dos resultados, inferência e interpretação - etapa na qual as evidências foram tratadas, interpretadas e analisadas à luz das teorias de effectuation e empreendedorismo social. Ainda nessa terceira etapa realizou-se a cross-case analysis, por meio da qual buscou-se identificar diferenças e aspectos comuns entre os casos, bem como confrontar os resultados obtidos com o referencial teórico consultado (EISENHARDT, 1989).

A fim de preservar a identidade dos empreendimentos pesquisados, eles receberam a denominação fictícia de Associação Musical A e Creche Ação Social B. Os casos serão descritos a seguir considerando as categorias de análise do estudo: características do empreendedor, características do empreendimento social e princípios effectuation, levando em conta os pressupostos de definição dos meios, perdas acessíveis, alianças estratégicas e alavancagem de contingências. 


\section{DESCRIÇÃO DOS CASOS}

\section{Caso 1 - Associação Musical}

A Associação Musical A é uma entidade sem fins lucrativos localizada na cidade de Itabaianinha/SE, que atua com a promoção, ensino e prática coletiva da música, tendo como missão a inclusão de crianças e jovens no processo de construção da cidadania, bem como o desenvolvimento de suas potencialidades musicais e culturais. Esse projeto social iniciou e formalizou suas atividades em 3 de março de 2013, ofertando inicialmente aulas de percussão, e, posteriormente, de forma gradativa, foram incluídas aulas com instrumental de sopro, instrumentos de corda e aulas de dança. Atualmente a Associação é integrada por cerca de 110 componentes, distribuídos na banda de percussão, banda musical e corpo coreográfico.

O fundador, denominado de entrevistado 1, é casado, tem 2 filhos, é funcionário público municipal, possui Ensino Superior, iniciou a Associação aos 34 anos de idade e hoje é seu vice-diretor.

A criação desse empreendimento social foi resultante da participação de um grupo de pessoas que em colaboração com o empreendedor deram início à instalação da Associação. Percebe-se nessa etapa inicial a participação de pessoas próximas ao empreendedor que já possuíam vínculo afetivo com o ele e compactuavam com a intenção de dar início ao projeto. Conforme evidenciado na fala do entrevistado 1, a ideia de colocar o projeto em prática surgiu sem planejamento prévio e foi se ajustando no decorrer do tempo:

Se cria uma vontade, se cria um apego com as pessoas, na verdade a associação
foi mais um apego com as pessoas né, a gente vinha de outra instituição, vinha um
grupo trabalhando em torno de oito pra nove anos... existia um projeto na outra
instituição e foi interrompido por motivos da própria estrutura da outra instituição,
e aí boa parte do pessoal decidiu manter o projeto, mas com uma nova instituição,
começar uma nova estrutura, começar do zero mesmo, foi mais ou menos essa
ideia inicial que nós tivemos.

Na primeira fala do entrevistado percebem-se dois aspectos importantes relacionados à lógica de effectuation: criação de negócios sem planejamento e alavancagem de contingências. No caso em estudo, é claramente perceptível que a decisão de criar a Associação surgiu de um evento inesperado: a inadequação estrutural da instituição anterior. Foi a partir deste acontecimento que o empreendedor remodelou seu objetivo original e se aproveitou de uma contingência, transformando-a na oportunidade de criar o negócio social.

O entrevistado 1 relatou também que já vinha trabalhando com música há muito tempo, inclusive em outras instituições sociais do ramo musical. Sua experiência em empreendimentos sociais iniciou-se na cidade de Frei Paulo/SE, na qual atuou como auxiliar em cursos de ensino de música durante os anos de 2001 a 2004. Ainda em 2004 o entrevistado iniciou suas atividades no município de Itabaianinha/SE em uma instituição social musical, onde passou cerca de nove anos desenvolvendo o projeto. No decorrer desses nove anos, o entrevistado conjuntamente com os alunos passou a desenvolver um trabalho de aperfeiçoamento das atividades, iniciando a participação em 
campeonatos de bandas musicais e levando o nome da instituição mais adiante. Em decorrência de aspectos administrativos, porém, o projeto foi interrompido pela instituição, resultando na saída do entrevistado e de boa parte dos alunos mais antigos que, em conjunto, deram início à Associação Musical A.

Um fato que deve ser observado é com relação à escolaridade do empreendedor, que possui nível superior em área distinta da musical. No decorrer de sua vida, entretanto, ele fez diversos cursos voltados para a área musical, buscando aprimorar seus conhecimentos e a técnica instrumental. Outro fator explanado é com relação à experiência autodidata do empreendedor, ressaltando a facilidade que sempre teve para aprender a tocar instrumentos.

Com relação à parte administrativa do empreendimento, o entrevistado ressaltou que não teve dificuldades no gerenciamento da instituição e que já teve contatos com essa área administrativa, seja por meio de outras instituições, proximidade com gestores, além de cursos nessa área.

Fiz alguns cursos da parte administrativa do Sebrae, já tive passagem de experiência nessa questão de associações... então no manejo da questão da Associação não tive muita dificuldade, mas pela experiência que eu sempre convivi com muitas pessoas sobre isso... pessoas que são secretários, com gestores, com os cursos que eu fiz nessa área de administração também.

Conforme relatado, quanto a sua personalidade, o empreendedor tem apreço natural por música, assim como habilidade para tocar diferentes instrumentos musicais. Quanto aos conhecimentos destacam-se a vasta experiência e a familiaridade do empreendedor no ramo de atividade do projeto criado, inclusive na parte administrativa, para a qual fez alguns cursos profissionalizantes. E, sobretudo, contava com uma rede de contatos que partilhava dos mesmos interesses e objetivos quanto à constituição de um negócio social.

Muitas dificuldades tornam-se evidentes na instituição de empreendimentos sociais, sendo em sua maioria pertinente à escassez de recursos imprescindíveis para que negócios sociais tenham continuidade. No caso analisado a dificuldade evidenciada desde o princípio do projeto, e vista como a de maior relevância até hoje, é a não disponibilidade de uma sede própria. Nesses quase quatro anos de existência da instituição, esta já passou por cinco locais diferentes e atualmente está sediada em um espaço locado pela prefeitura do município, porém, com a garantia de pagamento apenas até o final do ano de 2017.

Com relação às redes de relacionamento e parcerias estratégicas, foi possível evidenciar que a rede de contatos do empreendedor também lhe forneceu novos conhecimentos, habilidades, reconhecimento e legitimidade para o projeto. Boa parte do instrumental foi resultado de empréstimos obtidos com a rede de contatos do empreendedor, e a parte adquirida foi em sua maioria de material usado. Alguns ceramistas e empresários do município de Itabaianinha/SE também acreditaram no projeto que estava sendo executado e colaboraram com recursos financeiros, que serviram para a aquisição de instrumentos musicais. Vale ressaltar a garra e determinação dos membros da instituição, que por meio da venda de rifas conseguiram auferir recursos. Conforme explana o entrevistado 1 : 
Dos recursos, é como se diz, como nós acreditamos na gente mesmo, algumas pessoas, alguns ceramistas acreditaram, então chegamos lá e as pessoas deram material, então começou com alguma ajuda da parte do comércio... e claro também teve rifa né, muita rifa para conseguir material.

É perceptível que o empreendedor contava com uma rede de contatos diretos - ex-alunos e cofundadores - que partilhavam dos mesmos interesses e objetivos quanto à constituição de um negócio social. Mais que uma rede de contatos, esses ex-alunos formavam uma valiosa aliança estratégica. Essas pessoas, por já serem detentoras de conhecimento musical, devido aos muitos anos de estudo e participação no outro projeto, foram de grande importância nessa fase inicial, pois repassaram seus conhecimentos aos novos participantes. Além desses, o entrevistado 1 constituiu alianças estratégicas, ainda que informais, com empresários da localidade, as quais lhe proveram acesso a recursos financeiros imprescindíveis ao início das atividades da Associação. Para o entrevistado 1, essas parcerias foram importantes para o início do projeto, bem como para sua continuidade, tendo em vista a escassez de recursos disponíveis, conforme explana: "Não adianta você ter uma grande habilidade profissional se você não tem os contatos... nesse caso específico foram de fato os contatos e as amizades."

No que concerne ao princípio de perdas acessíveis e levando-se em conta a escassez de recursos e materiais no início do projeto, pouco se pensou sobre possíveis perdas toleráveis. 0 entrevistado 1 declarou que:

Posso pensar em uma perda moral, né... na verdade pode-se pensar nessa questão de ego, mas não no sentido de perdas porque a gente não investiu em nada, né... poderia se ter perda na questão da confiança de algum patrocinador.

Em termos financeiros o empreendedor demonstrou que não aceita perdas, porque todo recurso adquirido é devidamente aplicado no negócio, sem direito a erros na sua aplicação. 0 entrevistado 1 , contudo, deixou transparecer uma preocupação com sua reputação, com sua moral e o quanto isso poderia impactar no desempenho da Associação Musical A.

Já em relação à alavancagem de contingências, o entrevistado 1 evidenciou que alguns instrumentos que tinham sido emprestados tiveram de ser devolvidos antes do tempo, resultando em uma dificuldade inesperada, porém, conforme citado anteriormente, o empreendedor recorreu à sua rede de relacionamentos e parcerias para tentar minorar os efeitos dessa contingência. Essas situações inesperadas, no entanto, são vistas de forma positiva, tendo em vista que a cada problema solucionado a instituição ganha mais força para continuar atendendo à sociedade, e que quando surgem situações semelhantes a forma de resolver será mais fácil, dada a experiência acumulada:

Surgiu um problema em determinada situação, aí a gente se desgastou pra resolver aquele problema, mas se surgir um problema similar, você não vai se desgastar tanto porque você já sabe como resolver, você já tem como nesse caso ser um pouco mais eficiente sem desgaste, então às vezes o problema nos ensina a resolver outros de melhor forma. 
Pode-se perceber ainda que o entrevistado 1 possui o desejo de ampliar as atividades da instituição, podendo aumentar o número de pessoas atendidas pelo projeto, bem como atender à população mais carente do município. Conforme destacado desde o início da entrevista, todavia, a escassez de recursos acaba por inviabilizar esse desejo, tendo em vista que a estrutura até então disponível não comportaria tal ampliação:

Claro que a gente tinha vontade de atuar na periferia, totalmente na periferia, mas tem que ter estrutura, né, a gente tinha vontade de ter muita coisa, e a gente luta pra isso, corre aqui, corre ali, mas às vezes as condições não ajudam... então assim, poderia ser bem melhor, mas é o que nós podemos fazer agora... o que foi trabalhado até hoje, acho que tudo foi trabalhado dentro do possível, claro que a gente queria que fosse melhor.

\section{Caso 2 - Creche Ação Social B}

Criada em 2003, a Creche Ação Social B é uma entidade social do terceiro setor que atende crianças da cidade de Nossa Senhora do Socorro, situada na região metropolitana de Aracaju, SE. O empreendimento social conta, atualmente, com 16 funcionários para o atendimento de 86 crianças entre 0 e 5 anos. A creche oferece serviços básicos de alfabetização, alimentação, atendimento médico e odontológico. Além disso, disponibiliza cestas básicas e assistência funeral para famílias carentes da região.

O fundador, aqui identificado como entrevistado 2, é uma figura conhecida do cenário social local de Aracaju. Nascido em junho de 1969, foi abandonado pelos pais aos 4 anos de idade, viveu num orfanato por 13 anos, aos 17 anos começou a trabalhar com crianças carentes e aos 33 anos inaugurou a creche. Solteiro, tem 2 filhos, e estudou apenas até a 3a série do Ensino Fundamental.

O empreendedor relata que na época da criação do empreendimento não possuía muitos recursos financeiros, apenas o lucro adquirido com a venda de picolés e sua vontade de ajudar as pessoas. Aliás, naquela época o empreendedor nem mesmo havia definido em qual vertente social pretendia se engajar, conforme destacou:

Eu nem sabia que queria construir uma creche, eu só sabia que queria ajudar as pessoas, como eu já fazia um trabalho social lá na vila em que morava um dia eu saí numa matéria do Jornal Hoje. Então um empresário me deu esse terreno aqui, e foi ali naquela hora que eu decidi fazer a creche, mesmo sem ter o dinheiro pra levantar isso aqui.

Quanto aos meios relacionados à personalidade do empreendedor, identificados a partir de questões como quem eu sou, foram altamente influentes as suas habilidades e gostos pessoais, principalmente o apego e facilidade em lidar com crianças, como relata:

Eu sempre gostei de crianças, de ajudar, de fazer bem, isso já é de mim mesmo, irmão. Eu sempre soube que ajudar as pessoas era uma missão que Deus me deu, e principalmente as crianças que eu gosto demais e elas de mim.

Quanto ao segundo tipo de meios, aqueles que envolvem conhecimentos, escolaridade e experiência, o empreendedor revelou que estudou apenas até a 3 a série do Ensino Fundamental, mas mesmo que não tivesse estudado teria igual aptidão para ne- 
gócios sociais. No tocante às experiências anteriores, o entrevistado relatou que o fato de já realizar atividades sociais, ainda que em menor proporção, o fizeram crer ser possível construir e manter uma creche.

É claro que eu não sabia como é cuidar de uma creche, cuidar de funcionários e pagar salários, mas eu já sabia conviver com as pessoas, dificuldade existe pra tudo na vida, né?! Mas como eu era vendedor ambulante, e eu mesmo organizava as mercadorias, por quanto ia vender e como ia usar o dinheiro, então isso me ajudou a controlar o dinheiro das doações que recebia e como aplicar para levantar esse prédio aqui.

Em relação à rede de contatos, foi interessante perceber que o empreendedor não dispunha de uma rede de contatos diretos, e para superar essa dificuldade dedicava-se, diariamente, a sair de porta em porta pedindo doações. Conforme destaca, "as doações dos mais pobres aos mais ricos" é que formavam sua rede de contatos e, a partir delas o empreendedor reforçava seu objetivo e sonho de construir e colocar em funcionamento seu negócio social. Questionado a respeito de quais os meios mais importantes para criação do empreendimento, o empreendedor foi categórico ao afirmar: "Com certeza foi o meu jeito mesmo, porque eu gosto disso, perante a Deus, eu gosto de ajudar as pessoas, e em segundo lugar são as pessoas que confiam em meu trabalho e fazem as doações".

Em referência às alianças estratégicas, o empreendedor do caso 2 apontou que durante a constituição do negócio recebeu ajuda de empresários que se solidarizaram com sua causa e entusiasmo social, a exemplo do empresário que lhe doou o terreno no qual hoje funciona o empreendimento, e outro que construiu um pequeno quarto para o empreendedor nas proximidades da creche. O empreendedor destaca:

Eu não posso apontar pra uma pessoa ou grupo como aliança estratégica porque desde o início daqui que eu recebo ajuda de todo mundo, do mais rico ao mais pobre.

O entrevistado também frisou que, durante o processo de criação do empreendimento, sua rede de contatos, apresentada como o conjunto de doadores e colaboradores diários, contribuiu com recursos físicos, tais como doações de telhas, madeira e demais materiais de construção.-

O empreendedor destacou o papel da imprensa (TV e rádio), que embora não tivesse um elo formal com o empreendimento, foi imprescindível para a criação do negócio. Relatou inclusive que sempre que saía às ruas para pedir doações ouvia comentários acerca de sua história ter sido noticiada no rádio e/ou na TV. Essa divulgação voluntária por parte da mídia legitimou o seu trabalho. Como explica:

Toda vez que a crise aperta eu vou para o sinal para completar o valor para manter as atividades da creche, e certa vez uma delegada de Polícia do Estado de Minas Gerais que estava na cidade me reconheceu por já ter me visto em uma matéria na TV e me doou todo o piso para revestimento de uma das salas aqui do prédio.

No que concerne às perdas acessíveis, o empreendedor informou que perdas, principalmente financeiras, não são toleradas. Ele esclarece: "Aqui a gente vive de doações, da bondade do povo, não dava para aceitar nada como perdas não, tudo que eu recebia era usado pra levantar a creche, não dava para perder, dava mais para faltar." 
Referente ao acontecimento de situações inesperadas o empreendedor do caso 2 relatou que: "O evento inesperado já era não ganhar doações, mas isso nem era inesperado, eu tinha meus pés no chão que isso podia acontecer, mas eu sabia também que não iria parar só porque as doações aumentaram ou diminuíram".

Assim, a respeito da alavancagem de contingências, o empreendedor não relatou eventos inesperados que o fizessem remodelar objetivos ou visualizar novas oportunidades.

\section{ANÁLISE COMPARATIVA DOS CASOS}

A comparação entre os casos da Associação Musical e da Creche Ação Social, assim como a comparação destes com a literatura, trouxe à tona algumas evidências e particularidades quanto à aplicação de elementos de effectuation em empreendimentos sociais.

Para melhor exposição das evidências identificadas nos casos analisados, a análise dos resultados seguirá a ordem das categorias analíticas propostas, logo: definição dos meios, perdas acessíveis, alianças estratégias e alavancagem de contingências, respectivamente. O Quadro 4 resume os principais resultados identificados nos casos analisados.

Quadro 4 - Princípios de Effectuation em Empreendimentos Sociais

\begin{tabular}{|c|c|c|c|}
\hline \multicolumn{2}{|c|}{ Effectuation } & Associação Musical & Creche Ação Social \\
\hline \multirow{7}{*}{ Definição dos meios } & \multirow[t]{2}{*}{ Habilidades } & $\begin{array}{l}\text { Facilidade com instrumentos } \\
\text { musicais }\end{array}$ & Vontade de ajudar pessoas \\
\hline & & Gosto pela música & Apego a crianças \\
\hline & \multirow{4}{*}{ Conhecimentos } & $\begin{array}{l}\text { Experiência com negócios } \\
\text { sociais }\end{array}$ & $\begin{array}{l}\text { Experiência com negócios } \\
\text { sociais }\end{array}$ \\
\hline & & $\begin{array}{l}\text { Cursos voltados à área de } \\
\text { música }\end{array}$ & \multirow{3}{*}{$\begin{array}{l}\text { Experiência como vendedor } \\
\text { ambulante }\end{array}$} \\
\hline & & Emprego atual como regente & \\
\hline & & $\begin{array}{l}\text { Cursos profissionalizantes na } \\
\text { área de gestão }\end{array}$ & \\
\hline & Rede de contatos & Ex-Alunos & Doadores de modo geral \\
\hline \multirow{2}{*}{\multicolumn{2}{|c|}{$\begin{array}{l}\text { Perdas acessíveis } \\
\text { Moral (Reconhecimento) }\end{array}$}} & Tempo & \multirow[b]{2}{*}{ Não foi observado } \\
\hline & & & \\
\hline \multirow{2}{*}{\multicolumn{2}{|c|}{$\begin{array}{l}\text { Parcerias } \\
\text { Empresários }\end{array}$}} & Ex-alunos & Empresários \\
\hline & & Imprensa (TV, rádio e Internet) & \\
\hline \multicolumn{2}{|c|}{$\begin{array}{l}\text { Contingências } \\
\text { Devolução de equipamentos musicais }\end{array}$} & $\begin{array}{l}\text { Desligamento da instituição } \\
\text { anterior }\end{array}$ & Não receber doações \\
\hline
\end{tabular}

Fonte: Elaborado pelos autores (2016).

Conforme menciona Sarasvathy (2008), os empreendedores iniciam seus negócios a partir dos meios disponíveis, sem uma clara definição quanto a seus objetivos, assim como sem um planejamento prévio, minucioso e detalhado. Esta evidência foi percebida no caso 2, quando o empreendedor destacou que não houve planejamento formal para criação do empreendimento social, tendo sido motivado por sua vocação para ajudar as pessoas, assim como por ter, inesperadamente, ganhado o terreno de um empresário. 
Daniel, Di Domenico e Sharma (2015) observam que ao utilizar a lógica effectuation o empreendedor é capaz de criar oportunidades e estruturar negócios na ausência de recursos, assim como de mudar seus objetivos iniciais ou cursos de ação com base em novas informações e/ou contingências que venham a surgir inesperadamente. Essa indicação pode ser percebida no caso 1, quando o empreendedor destacou que a decisão de criar a Associação surgiu de um evento inesperado, a inadequação estrutural da instituição anterior. Foi a partir desse acontecimento que o empreendedor remodelou seu objetivo original e se aproveitou de uma contingência, transformando-a na oportunidade de criar o negócio social. Essa evidência vai ao encontro do postulado por Sarasvathy (2001) de que em effectuation o empreendedor toma decisões por senso de oportunidade, sem um objetivo predeterminado, e pelo qual as metas surgem à medida que os fatos acontecem.

Pode-se destacar na definição dos meios que ambos os empreendedores constituíram negócios sociais em atividades com afinidades com suas respectivas personalidades, contudo, enquanto o empreendedor do caso 1 evidencia sua rede de contatos e parcerias como elementos vitais desde a ideia até a primeira atividade da associação, o empreendedor do caso 2 acredita que sua vontade pessoal foi imprescindível para iniciar o negócio.

Outra importante distinção entre os casos diz respeito aos conhecimentos utilizados por cada empreendedor. O empreendedor do caso 1 fez maior uso do conjunto de conhecimentos e experiências acumulados ao longo de sua vida, enquanto que no caso 2 percebeu-se que o baixo grau de escolaridade do empreendedor, que afirmou inclusive ler muito pouco, não foi empecilho à constituição do negócio. Além do mais, no tocante às experiências sociais, ambos os empreendedores já reconheciam, ainda que parcialmente, o ambiente em que iriam operar e isso facilitou a criação e atuação mais eficaz do negócio.

Sarasvathy (2008) reiterou que os empreendedores iniciam negócios de acordo com os meios disponíveis e os possíveis efeitos que podem ser realizados a partir de tais meios. Os empreendedores analisados, em maior ou menor grau, valeram-se de seus meios, mas é importante destacar que, nem todos os meios tiveram a mesma relevância para constituição dos negócios sociais, mas que personalidade, conhecimentos e rede de contatos foram utilizados por ambos os empreendedores.

Em termos financeiros os empreendedores demonstraram que não há tolerância para perdas, porque todo recurso adquirido é devidamente aplicado no negócio, inclusive quaisquer tipos de perdas são, explicitamente, evitados. Vale ressaltar que de modos distintos os empreendedores desenvolveram estratégias de ação para minorar os efeitos dos riscos advindos por perdas, no caso 1 acumulação de conhecimentos e no caso 2 intensificação dos pedidos de doações. Essas constatações são corroboradas por Read, Song e Smit (2009), que apontam que o que importa na perda acessível não é somente o risco referente ao empreendimento individual, mas sim o quanto o empreendedor sabe administrar o risco.

É interessante destacar que o empreendedor do caso 1, além de perdas financeiras, demonstrou certa preocupação quanto a perdas como o reconhecimento moral e social do empreendimento. Essa preocupação é confirmada por Nogueira e Nogueira (2012), que destacam que além de recursos financeiros o empreendedor defi- 
ne um limite para perdas com tempo e status. No tocante a perdas com tempo foi interessante perceber que os empreendedores, em nenhum momento, abandonaram suas ocupações profissionais em decorrência do projeto social.

Referente à rede de relacionamentos e parcerias estratégicas percebeu-se que no caso 1 a rede de contatos, formada por ex-alunos, era mais próxima e de maior convívio com o empreendedor. No segundo caso, a rede de contatos era formada por pessoas e instituições que não tinham proximidade física e parental com o empreendedor. Nesse caso, a rede de relacionamentos e parcerias estratégicas se confundem, uma vez que são caracterizadas como todos os doadores da entidade. Essas constatações são corroboradas por Nielsen e Lassen (2012), que esclarecem que após identificar os meios a sua disposição o empreendedor inicia um processo de pequenos passos em que interage com outras pessoas, constituindo parcerias e alianças estratégicas, para obter acesso a recursos, conhecimentos e habilidades que não estão sob seu controle.

Importante aspecto evidenciado nas parcerias dos casos estudados é que estas ocorrem em razão do reconhecimento social dos empreendedores. Aliás, a figura do empreendedor social foi elemento de destaque para motivar a criação e manutenção de uma rede de contatos, estimular alianças estratégicas e fornecer reconhecimento e legitimidade para esses negócios.

No que respeita à rede de relacionamentos e parcerias estratégicas, ficou explícito que empreendimentos sociais não sobrevivem sem elas. Sem essas parcerias, capazes direta ou indiretamente de captar recursos para o empreendimento, sejam eles financeiros, humanos ou de legitimação, o empreendimento social terá poucas chances de sobrevivência (OHLSSON-CORBOZ, 2013). É importante destacar, conforme foi verificado nos casos, que as parcerias estratégicas não necessariamente precisam se constituir em laços formais, sua operacionalização parte da voluntária e natural interação das partes envolvidas, isto é, não são parcerias desenhadas e planejadas, e sim que natural e informalmente se constituem.

Read, Song e Smit (2009) esclarecem que a alavancagem de contingências é caracterizada pelo aproveitamento de situações inesperadas para remodelar objetivos e explorar novas oportunidades. Essa evidência foi verificada no caso 1, uma vez que a Associação Musical A nasceu de uma contingência: o aborto de um projeto semelhante em outra instituição. Além disso, o empreendedor considera de forma positiva o surgimento e resolução de situações inesperadas, tendo em vista que, a cada problema solucionado, a instituição ganha força para continuar atendendo à sociedade, assim como acumula conhecimentos e experiências para resolução de situações futuras. Essa evidência é ratificada por Vansandt, Sud e Marmé (2009), que apontam que a experiência acumulada na resolução de problemas e superação de contingências se constitui em um catalisador para melhor desempenho de negócios sociais.

Já no segundo caso as contingências foram sempre descritas em termos do não recebimento de doações. Nesse caso, a alavancagem de contingências não foi visualizada como um instrumento para mudar objetivos e reduzir incertezas.

A partir das informações expostas no Quadro 4 a respeito dos casos analisados, foi proposta uma estrutura analítica, apresentada na Figura 2, que mostra como os pressupostos de effectuation foram identificados nos casos selecionados. Explica-se que essa 
estrutura analítica considerou os princípios de definição de meios, perdas acessíveis, parcerias e contingências (SARASVATHY, 2001). Conforme é apresentado na Figura 2, ao utilizar princípios effectuation os empreendedores sociais identificam os meios sobre os quais detêm algum controle e/ou acesso, prioritariamente aqueles relacionados a habilidades e conhecimentos pessoais, assim como a rede de contatos disponível. Num segundo momento esses empreendedores definem quais perdas serão toleradas em termos de tempo, reputação e recursos financeiros.

A definição das parcerias estratégicas é um dos principais pontos do processo effectual, e conforme defendido por Ohlsson-Corboz (2013), a realização de boas parcerias é imprescindível à continuidade de empreendimentos sociais. Na Figura 2 pode-se verificar como as parcerias estão diretamente relacionadas com as contingências, isto porque a ausência de parcerias pode resultar em situações inesperadas, ao passo em que o surgimento de eventos inesperados desperta nos empreendedores maior atenção para a realização de boas parcerias para contornar o efeito de contingências. Conforme indicam as setas na estrutura analítica proposta as parcerias estão diretamente relacionadas com a definição de meios, uma vez que as habilidades, conhecimentos e rede de contatos do empreendedor são influentes para a constituição de parcerias, conforme percebido nos casos estudados.

Figura 2 - Princípios de Effectuation em Empreendimentos Sociais

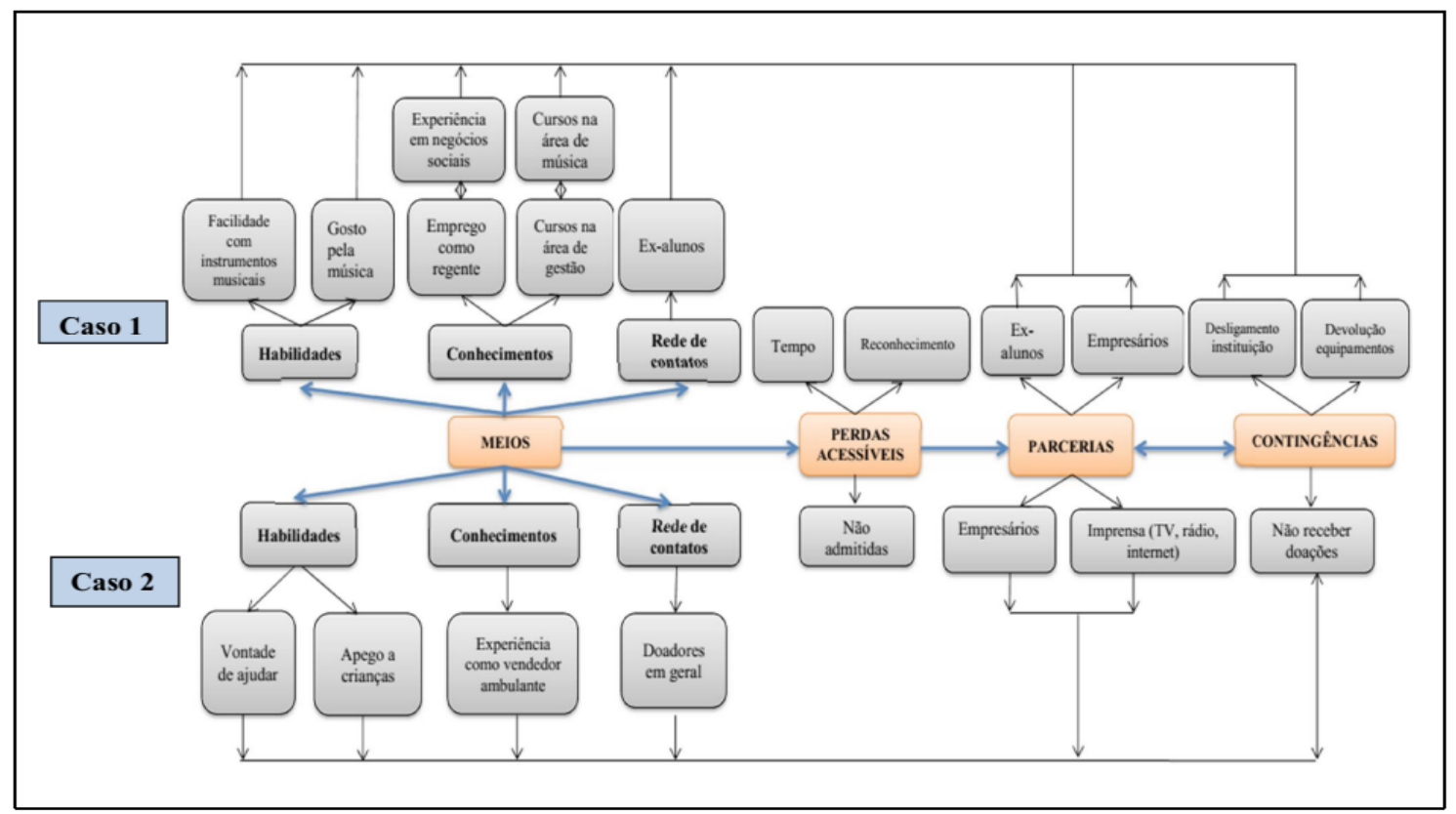

Fonte: Elaborada pelos autores (2017).

Analisados à luz dos princípios de effectuation, foi claramente perceptível que o caso 1 utilizou-se de todos os pressupostos dessa abordagem. Notoriamente, a definição de meios e parcerias estratégicas foram os elementos mais relevantes à constituição da Associação Musical. O caso 2, por sua vez, nem sempre foi fiel aos princípios defendidos por Sarasvathy (2001). Destaca-se que, nesse caso, a alavancagem de contingências não foi relatada como um instrumento para mudar objetivos e reduzir incertezas, bem como não foram claramente identificadas evidências relacionadas ao princípio de perdas acessíveis. 


\section{CONSIDERAÇÕES FINAIS}

Este trabalho buscou, por meio de um estudo de casos múltiplos, analisar o processo de criação de empreendimentos sociais a partir da abordagem effectuation. Os resultados apontaram que os empreendedores sociais aplicam vários dos princípios propostos por Sarasvathy (2001), principalmente os relacionados com a definição de meios e parcerias estratégicas. Quanto à definição de meios, deve-se ressaltar a importância da personalidade e rede de contatos dos empreendedores na decisão e atividades relacionadas à constituição do empreendimento. Um fato que merece destaque é que a escolaridade dos empreendedores estudados foi sempre colocada como elemento adicional e não primordial na decisão de criar um negócio social. Evidencia-se, contudo, que, ainda que indiretamente, o grau de instrução e conhecimento formal dos empreendedores foi utilizado na criação e gestão dos empreendimentos pesquisados.

Percebeu-se também que parcerias estratégicas, ainda que não formalizadas, são essenciais à continuidade de um projeto social, uma vez que elas funcionam como amortecedores para situações inesperadas. Por situações inesperadas, nos casos verificados, entende-se o não recebimento de doações. Para Ohlsson-Corboz (2013), empreendimentos sociais que não constituem eficazes parcerias tendem a não sobreviver ou ter mínimo impacto social. Essa afirmação pode ser claramente percebida nos casos estudados.

Quanto às perdas acessíveis, notou-se que em um dos casos havia uma preocupação com perdas morais e de reconhecimento do trabalho do empreendimento, mas em nenhum dos casos observou-se preocupação com perdas financeiras, não por não haver uma responsabilidade sobre o tema, mas sim por existir uma plena conviçcão, em ambos os casos, que em negócios sociais, mantidos por doações, perdas não são toleráveis.

Nos casos analisados percebeu-se que os empreendedores contemplam todos os elementos propostos pela lógica effectuation, mas não necessariamente numa sequência. Por exemplo, as parcerias podem consolidar-se antes mesmo da identificação dos principais meios do empreendedor. Um destaque em empreendimentos sociais no tocante a contingências é que o ambiente em que esses negócios operam já é repleto de contingências e os empreendedores estão mais preocupados em superá-las e acumular conhecimento ao invés de transformá-las em oportunidades. Aqui cabe ressaltar que para lidar com situações inesperadas, os empreendedores num primeiro momento fazem uso de elementos effectuation, mas à medida que essas situações começam a se repetir eles adotam um modelo de reação que segue a lógica causation.

Recomendam-se novos estudos com a finalidade de analisar como as contingências influenciam na identificação de oportunidades para a criação de empreendimentos socais, assim como um estudo longitudinal a fim de analisar em que momento os empreendimentos sociais abandonam a lógica effectuation e adotam a lógica causation. Ademais, seria interessante uma investigação mais aprofundada sobre os níveis de desempenho e sobrevivência de negócios sociais que adotam essas abordagens para tomadas de decisão. 


\section{REFERÊNCIAS}

BARDIN, L. Análise de conteúdo. Lisboa: Edições 70, 2006. (Obra original publicada em 1977).

BARKI, E. Negócios de impacto: tendência ou modismo? GVexecutivo, São Paulo, 14(1), p. 14-17, 2015.

BOSE, M. Empreendedorismo social e promoção do desenvolvimento local - SP. 2012. $182 \mathrm{f}$. Tese (Doutorado em Administração) - Faculdade de Economia, Administração e Contabilidade, Universidade de São Paulo, São Paulo, 2012.

BRANSKI, R.; FRANCO, R.; LIMA JR., O. F. Metodologia de estudo de casos aplicada à logística. In: XXVII ANPET - CONGRESSO DE PESQUISA E ENSINO EM TRANSPORTE, 2013. Belém do Pará. Anais [...]. Belém do Pará, 2013. Disponível em: http://www.anpet.org.br/xxviianpet. Acesso em: 5 jan. 2017.

CAMPOS, T. et al. Produção científica brasileira sobre empreendedorismo social entre 2000 e 2012. Revista de Empreendedorismo e Gestão de Pequenas Empresas, 1(2), p. 60-89, 2012.

CHANDLER, G. et al. Causation and effectuation processes: a validation study. Journal of Business Venturing, 26(1), p. 375-390, 2011.

CORNER, P.; HO, M. How Opportunities Develop in Social Entrepreneurship. Entrepreneurship: Theory and Practice, 34(4), p. 635-659, 2010.

DACIN, M.; DACIN, P.; TRACEY, P. Social entrepreneurship: A critique and future directions. Organization Science, 22(5), p. 1.203-1.213, 2011.

DANIEL, E.; DI DOMENICO, M. L.; SHARMA, S. Effectuation and home-based online business entrepreneurs. International Small Business Journal, 33(8), p. 799-823, 2015.

DEES, G. The Meaning of Social Entrepreneurship. 2001. Disponível em: http://www.caseatduke.org/documents/dees_sedef.pdf.

DEES, G. "Social Ventures as Learning Laboratories". Innovations. Special Edition for the World Economic Forum Annual Meeting 2009, p. 11-15, 2009.

DEW, N. et al. Effectual versus predictive logics in entrepreneurial decision-making: Differences between experts and novices. Journal of Business Venturing, 24, p. 287-309, 2009.

DEW, N. et al. Outlines of a behavioral theory of the entrepreneurial firm. Journal of Economic Behavior \& Organization, 66, p. 37-59, 2008.

EISENHARDT, K. Building Theories from Case Study Research. The Academy of Management Review, 14(4), p. 532-550, 1989.

FISCHER, R. Empreendedorismo social: apontamentos para um debate. In: CENTRO RUTH CARDOSO (org.). Políticas sociais - ideias e práticas. 1. ed. São Paulo: Ed. Moderna, 2011. p. 183-206.

FISHER, G. Effectuation, causation, and bricolage: a behavioral comparison of emerging theories in entrepreneurship Research. Entrepreneurship: Theory and Practice, 36(5), p. 1.019-1.051, 2012.

GALKINA, T.; CHETTY, S. Effectuation and networking of internationalizing SMEs. Management International Review, 55, p. 647-676, 2015.

GONZÁLEZ, J. M. R.; AÑEZ, M. E. M.; MACHADO, H. V. Raciocínio effectual e raciocínio causal na criação de novos negócios: um estudo de caso. Revista Ibero-Americana de Estratégia-RIAE, 10(2), 140-158, 2011. GOUVÊA, A.; CAUTELA, A. Empreendedorismo social: a experiência da organização Surya. Revista Acadêmica Eletrônica Sumaré - Raes, 8, 2014.

HARMS, R.; SCHIELE, H. Antecedents and consequences of effectuation and causation in the international new venture creation process. Journal of International Entrepreneurship, 10, p. 95-116, 2012.

HARTIGAN, P.; ELKINGTON, J. Empreendedores sociais: o exemplo incomum das pessoas que estão transformando o mundo. Rio de Janeiro: Elsevier, 2009.

HILL, T.; KOTHARI, T.; SHEA, M. Patterns of Meaning in the Social Entrepreneurship Literature: A Research Platform. Journal of Social Entrepreneurship, 1, p. 5-31, 2010.

HOOGENDOORN, B.; PENNINGS, E.; THURIK, R. What Do We Know about Social Entrepreneurship? An Analysis of Empirical Research. International Review of Entrepreneurship. Senate Hall Academic Publishing, p. 1-42, 2010.

KORSGAARD, S. Opportunity Formation in Social Entrepreneurship. Journal of Enterprising Communities: People and Places in the Global Economy, 5(4), p. 265-285, 2011.

KUPPER, D.; BURKHART, T. Effectuation in the context of R\&D projects: Characteristics and impact on Project performance. Academy of Management Proceedings, 1, p. 1-6, 2009.

MAINE, E.; SOH, Pek-Hoo; SANTOS, N. The role of entrepreneurial decision-making in opportunity creation and recognition. Technovation, 39-40(5), p. 53-72, 2015. 
MAIR, J.; MARTÍ, I. Social entrepreneurship research: a source of explanation, prediction, and delight. Journal of World Business, n. 41, p. 36-44, 2006.

MARTÍ, A.; SORIANO, D.; MARQUÉS, D. A Bibliometric Analysis of Social Entrepreneurship. Journal of Business Research, 69(5), 1.651-1.655, 2016.

MARTIN, R. L.; OSBERG, S. Social Entrepreneurship: The Case for Definition. Stanford Social Innovation Review, 5(2), p. 27-39, 2007.

MARTIN, R. L.; OSBERG, S. Dois fatores-chave para o empreendedorismo social sustentável. Harvard Business Review Brasil, maio 2015. Disponível em: http://hbrbr.com.br/dois-fatores-chave-para-o-empreendedorismo-social- sustentavel/. Acesso em: 28 jan. 2017.

MIRANDA, C. et al. Design e engenharia: um case de empreendedorismo social, 888-899. In: CONGRESSO BRASILEIRO DE PESQUISA E DESENVOLVIMENTO EM DESIGN, 12., 2016. São Paulo. Anais [...] São Paulo: Blucher, 2016. (Blucher Design Proceedings, 9(2)).

NEUMAN, W. Social research methods, qualitative and quantitative approaches. 3. ed. Boston: Allyn and Bacon, 1997.

NICHOLLS, Alex (ed.). Social Entrepreneurship: New models of sustainable social change. Oxford: Oxford University Press, 2006.

NIELSEN, S.; LASSEN, A. Identity in entrepreneurship effectuation theory: a supplementary framework. International Entrepreneurship Management Journal, 8, p. 373-389, 2012.

NOGUEIRA, L.; NOGUEIRA, T. Effectuation Logic in Social Entrepreneurship. 2012. 70f. Dissertação (MSc in Innovation, Knowledge and Entrepreneurial Dynamics) - Department of Business and Management, Aalborg University, 2012.

OHLSSON-CORBOZ, A. Effectual entrepreneurship and the social enterprise: an examination of the fit between the principles of effectuation and the sphere of the social enterprise as a form of new venture. 2013. 214f. Tese (Doutorado em Filosofia) - RMIT University, Austrália, 2013.

OLIVER, C.; MCKAGUE, K. Sustainable Local Enterprise Networks: Network Bricolage as Institutional Entrepreneurship in Low-Income Economies. Paper presented at the Institutional Theory Conference. Edmonton: University of Alberta, 2009.

PARENTE, Cristina et al. Empreendedorismo social: contributos teóricos para sua definição. ENCONTRO NACIONAL DE SOCIOLOGIA INDUSTRIAL, DAS ORGANIZAÇÕES E DO TRABALHO EMPREGO E COESÃO SOCIAL: DA CRISE DE REGULAÇÃO À HEGEMONIA DA GLOBALIZAÇÃO, 14., 2011. Lisboa. 26 e 27 maio 2011. Disponível em: https://repositorioaberto.up.pt/bitstream/10216/61185/2/cparenteempreendedorismo000151867.pdf. Acesso em: 10 dez. 2017.

PARENTE, C. Empreendedorismo social em Portugal. Porto: Universidade do Porto, 2014.

PELOGIO, E. et al. Criação de empresas à luz do modelo de decisão Effectuation: um estudo com mulheres empreendedoras no município de Currais Novos/RN. In: ENCONTRO ANPAD, 35., 2011. Rio de Janeiro. Disponível em: http://www.anpad.org.br/admin/pdf/ESO579.pdf . Acesso em: 16 maio 2016.

QUINTÃO, C. O Terceiro Sector e a sua renovação em Portugal. IS Working Papers, Porto: Instituto de Sociologia; Universidade do Porto, 2011.

READ, S.; SONG, M.; SMIT, W. A meta-analytic review of effectuation and venture performance. Journal of Business Venturing, 24, p. 573-587, 2009.

SARASVATHY, S.; DEW, N. Entrepreneurial logics for a technology of foolishness. Scandinavian Journal Management, 21, p. 385-406, 2005.

SARASVATHY, S.; KOTHA, S. Effectuation in the management of knightian uncertainty: evidence from the realnetwork case. UW Business School Working Paper, 2001.

SARASVATHY, S. Causation and Effectuation: Toward a Theoretical Shift From Economic Inevitability to Entrepreneurial Contingency. The Academy of Management Review, 26(2), p. 243-263, 2001.

SARASVATHY, S. Effectuation: Elements of Entrepreneurial Expertise. Northampton, MA, US: Edward Elgar Publishing, 2008.

SARASVATHY, S. Entrepreneurship as a Science of the Artificial. Journal of Economic Psychology, 24(2), p. 203-220, 2003.

SARMENTO, C. F. B.; CARVALHO, C. A. S.; DIB, L. A. R. Effectuation e a influência das redes sociais em internacionalização de startups em aceleradoras. InternexT - Revista Eletrônica de Negócios Internacionais da ESPM, 11(1), p. 63-76, 2016.

SEELOS, C.; MAIR, J. Social entrepreneurship: Creating new business models to serve the poor. Business Horizons, 48, p. 241-246, 2005.

SHARMA, P.; SALVATO, C. Commentary: Exploiting and Exploring New Opportunities Over Life Cycle Stages of Family Firms. Entrepreneurship Theory and Practice, 35(6), p. 1.199-1.205, 2011. 
SILVA, J. D.; TEIXEIRA, R. M.; MONTENEGRO, L. M. Effectuation na Criação de Spin-Offs Estudantis: Estudo de Múltiplos Casos em Aracaju, SE. In: VI ENCONTRO DE ESTUDOS EM EMPREENDEDORISMO E GESTÃO DE PEQUENAS EMPRESAS (EGEPE), 2014, Goiânia. Anais [...]. [S. I.: s. n.], 2014. Disponível em: http:// www.egepe.org.br/anais/tema01/44.pdf. Acesso em: 8 jan. 2017.

VANSANDT, C.; SUD, M.; MARMÉ, C. Enabling the Original Intent: Catalysts for Social Entrepreneurship. Journal of Business Ethics, 90(3), p. 419-428, 2009.

VIEIRA, I. Empreendedorismo e Effectuation: um estudo de caso sobre o processo de decisão na criação de novos negócios. 2014. 72 f. Dissertação (Mestrado profissionalizante em Administração) - Faculdade de Finanças Ibmec, Programa de Pós-Graduação em Administração e Economia, Rio de Janeiro, 2014.

VIEIRA, I.; BRITO, R. P. Empreendedorismo e Effectuation: Um Estudo de Caso sobre o Processo de Decisão. In: XXXVIII ENCONTRO DA ANPAD, 2014, Rio de Janeiro. Anais [...]. Rio de Janeiro: [s. n.], 2014. Disponível em: https://www.researchgate.net/publication/275210454_Empreendedorismo_e_Effectuation_Um_Estudo_de_Caso_sobre_o_Processo_de_Decisao. Acesso em: 04 jan. 2017.

WERHAHN, D. et al. Validating effectual orientation as strategic direction in the corporate context. European Management Journal, 33, p. 305-313, 2015.

WILTBANK, R. et al. What to do next? The case for non-predictive strategy. Strategic Management Journal, 27(10), p. 981-998, 2006.

YIN, R. K. Estudo de caso: planejamento e métodos. 5. ed. Porto Alegre: Bookman, 2015.

YUNUS, M. Creating a world without poverty: Social business and the future of capitalism. Global Urban Development, 4(2), p. 1-19, 2008.

YUSUF, J.; SLOAN, M. Effectual Processes in Nonprofit Start-Ups and Social. American Review of Public Administration, 45(4), p. 417-435, 2015. 